\title{
PENGELOMPOKAN WILAYAH INDONESIA DALAM MENGHADAPI REVOLUSI INDUSTRI 4.0 DENGAN METODE BICLUSTERING
}

\author{
(Indonesian Territorials Grouping in Facing the Industrial Revolution 4.0 Using Biclustering \\ Method)
}

\author{
Nurmawiya, Robert Kurniawan \\ Politeknik Statistika STIS \\ Jl Otto Iskandardinata No 64C, Jakarta 13330 \\ E-mail: 16.9340@stis.ac.id
}

\begin{abstract}
ABSTRAK
Indonesia sedang berada dalam era revolusi industri 4.0 yang mana untuk menghadapi era tersebut diperlukan kesiapan dari berbagai sisi terutama masyarakat. Era ini dapat memberikan keuntungan pertumbuhan ekonomi bagi Indonesia, akan tetapi dapat berakibat buruk berupa hilangnya sejumlah lapangan pekerjaan akibat adanya automasi. Oleh karena itu, kesiapan masyarakat memegang peranan penting dalam menghadapi era ini. Berkaitan dengan hal tersebut, penelitian ini dilakukan untuk mengelompokkan wilayah kabupaten/kota di Indonesia dengan menggunakan variabel indikator kesiapan yang terdapat dalam networked readiness index (NRI) oleh World Economic Forum (WEF). Metode pengelompokan yang digunakan adalah biclustering dengan algoritma Cheng dan Church. Pengelompokan dengan metode tersebut menghasilkan 5 bicluster di mana bicluster 4 adalah kelompok yang memiliki nilai rataan terendah untuk setiap variabel. Posisi terendah ini kemudian diikuti oleh bicluster 3. Berdasarkan hasil tersebut, pemerintah perlu menjadikan kabupaten/kota yang tercakup dalam bicluster 4 dan 3 sebagai prioritas dalam melakukan pembenahan untuk mempersiapkan masyarakatnya menghadapi revolusi industri 4.0.
\end{abstract}

Kata kunci: biclustering, Indonesia, industri 4.0, kesiapan masyarakat

\begin{abstract}
Indonesia is currently in the era of the industrial revolution 4.0, which to face this era requires the readiness from various sides, especially the community. This era can provide benefits for the economic growth of Indonesia, but also have negative consequences in the form of the loss of a number of jobs due to the automation. Therefore, the readiness of the community plays an important role in facing this era. In this regard, this research was conducted to classify regencies / cities in Indonesia using the readiness indicator variables contained in the networked readiness index (NRI) by the World Economic Forum (WEF). The grouping method used in this research was biclustering with the Cheng and Church algorithms. The result shows 5 biclusters where bicluster 4 has the lowest average for each variable. This position is then followed by bicluster 3. Based on these results, the government needs to make the regencies / cities covered by bicluster 4 and 3 as priority in making improvements to prepare their people for the 4.0 industrial revolution.
\end{abstract}

Keywords: biclustering, Indonesia, industry 4.0, community readiness

\section{PENDAHULUAN}

Indonesia telah memasuki fase keempat dari perkembangan revolusi industri, yaitu revolusi industri 4.0. Revolusi industri tersebut merupakan lanjutan dari revolusi industri ketiga dan berkembang dengan kecepatan yang bersifat eksponensial. Pada era ini bermunculan terobosanterobosan teknologi di berbagai bidang seperti kecerdasan buatan, robotika, internet of things, autonomous vehicles, 3-D printing, nanoteknologi, bioteknologi, materials science, penyimpanan energi, dan komputasi kuantum (Schwab, 2016). 
Berkenaan dengan revolusi industri tersebut, Indonesia telah meluncurkan kebijakan Making Indonesia 4.0 yang apabila berhasil diimplementasikan dapat mendorong pertumbuhan PDB riil sebesar 1 hingga 2 persen per tahun. Dengan demikian, pertumbuhan tersebut diperkirakan dapat meningkat dari baseline 5 persen menjadi 6 hingga 7 persen pada periode 2018-2030. Hal ini memberikan peluang untuk mempercepat pencapaian visi Indonesi menjadi 10 ekonomi terbesar dunia (Kementerian Perindustrian RI, 2018).

Namun, revolusi industri tersebut memiliki dampak berupa disrupsi dan hilangnya pekerjaan. Teknologi kecerdasan buatan dan robotika pada era ini mampu bekerja dengan baik dan lebih cepat, sehingga dapat mengurangi biaya dan meningkatkan produktivitas. Hal ini dapat menjadi ancaman bagi pekerjaan yang bersifat repetitif dengan keterampilan kerja yang rendah (WEF \& $A D B$, 2017). Digitalisasi industri pada era ini dapat berdampak negatif pada penyerapan tenaga kerja dan bisnis konvensional di Indonesia (Satya, 2018). Hasil estimasi dalam penelitian Chang \& Huynh (2016) dengan menggunakan metode oleh Frey \& Osborne menunjukkan terdapat sebanyak $56 \%$ pekerjaan di Indonesia berisiko tinggi mengalami automasi.

Implementasi industri 4.0 adalah keputusan strategis utama dan diperlukan penilaian terkait kesiapan untuk mengimplementasikannya (Rajnai \& Kocsis, 2018; Schumacher et al., 2016 dalam Sony, M. \& Naik S., 2019). Dalam hal ini World Economic Forum (WEF) telah membentuk networked readiness index (NRI). NRI adalah suatu ukuran yang dapat menunjukkan seberapa siap setiap negara untuk menuai manfaat dari adanya transisi dalam revolusi industri 4.0 (Breene, 2016). NRI menganalisis penggunaan teknologi informasi dan komunikasi (TIK) di suatu negara dan secara komparatif mengukur tingkat kesiapan negara dalam menggunakan TIK (Burma, 2016).

Ukuran tersebut tidak menilai kesiapan pada tingkat administrasi yang lebih kecil pada suatu negara. Selain itu, ukuran tersebut bersifat akumulatif dari variabel-variabel kompositnya, sehingga memerlukan rincian lebih lanjut untuk mengetahui aspek-aspek yang perlu diperbaiki. Oleh karena itu, penelitian ini dilakukan untuk memetakan kabupaten/kota yang ada di Indonesia berdasarkan indikator-indikator kesiapan yang terdapat pada NRI. Penelitian ini menggunakan metode biclustering karena metode tersebut mampu mengelompokkan setiap observasi berdasarkan variabel penciri yang sama. Dengan demikian, pengelompokan yang dihasilkan dapat memetakan daerah berdasarkan kesamaan sifat di setiap variabelnya.

\section{METODE}

Data yang digunakan dalam penelitian ini adalah data hasil survei sosial ekonomi nasional (SUSENAS) kor 2018 oleh Badan Pusat Statistik (BPS) yang dilaksanakan di 514 kabupaten/kota di Indonesia. Pada NRI terdapat 53 variabel yang digunakan sebagai indikator komposit (Baller, et. al., 2016). Akan tetapi, terbatasnya ketersediaan data yang ada menjadikan penelitian ini hanya menggunakan 9 variabel, yaitu angka melek huruf $(\mathrm{AMH})\left(X_{1}\right)$, angka partisipasi kasar (APK) sekunder $\left(X_{2}\right)$, APK tersier $\left(X_{3}\right)$, persentase penduduk menggunakan handphone (HP) $\left(X_{4}\right)$, persentase penduduk memiliki HP $\left(X_{5}\right)$, persentase penduduk menggunakan personal computer $(P C) /$ laptop $\left(X_{6}\right)$, persentase penduduk yang mengakses internet $\left(X_{7}\right)$, persentase rumah tangga yang memiliki aset PC/laptop $\left(X_{8}\right)$, dan persentase rumah tangga dengan sumber penerangan utama listrik $\left(X_{9}\right)$. Kemudian dengan menggunakan variabel-variabel tersebut dibentuk pengelompokan dengan metode biclustering.

Gagasan biclustering pertama kali diperkenalkan pada tahun 1972 oleh J.A. Hartigan dengan nama direct clustering (Mina et al., 2011). Biclustering adalah teknik unsupervised dalam data mining yang digunakan untuk membentuk kelompok skalar-skalar dari matriks dua dimensi. Biclustering berbeda dari clustering karena biclustering membentuk cluster secara simultan pada kedua dimensi data matriks. Dengan teknik tersebut submatriks yang berisi perilaku elemenelemen serupa dapat diungkap (Yuniarto \& Kurniawan, 2017). Berikut adalah visualisasi perbedaan hasil analisis antara clustering dan biclustering.

Tujuan dari analisis biclustering adalah untuk menemukan subset yang sebisa mungkin objek elemennya sama satu dengan lainnya berdasarkan sekumpulan variabel tertentu dan sebisa mungkin berbeda dari objek dan variabel lainnya yang tersisa (Kaiser, 2011). Gambar 1 
menunjukkan bahwa dengan pendekatan clustering dapat terbentuk subset yang beranggotakan gene 1, 4, 9 di mana objek-objek tersebut memiliki respon yang sama di setiap variabel. Sementara itu, dengan pendekatan biclustering dapat terbentuk subset yang beranggotakan gene $1,4,6,7,9$ yang memiliki kesamaan berdasarkan variabel $B, E$, F.

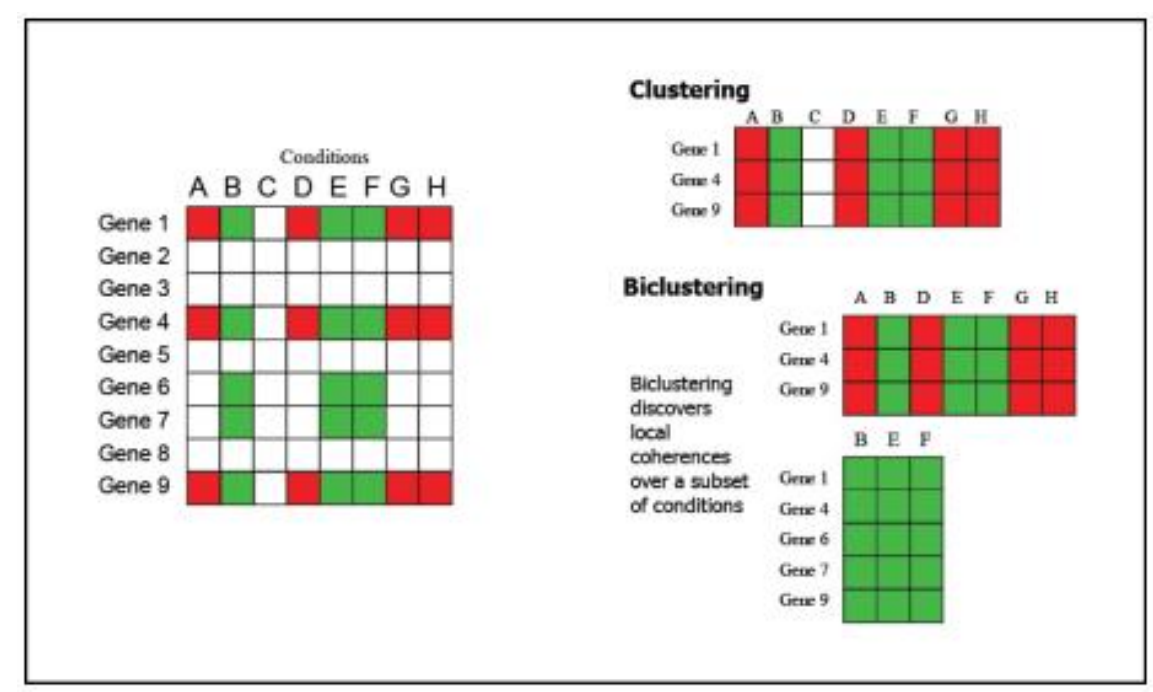

Gambar 1. Representasi outcome dari clustering dan biclustering.

Pada penelitian ini analisis biclustering yang digunakan adalah algoritma CC (Cheng \& Church) atau $\delta$-biclustering. Algoritma CC adalah algoritma serakah (greedy) yang mencoba untuk menemukan bicluster maksimal dengan kesamaan yang tinggi. Kumpulan baris dan kolom disebut bicluster jika memliki nilai mean squared residue di bawah level $(\delta)$ yang telah ditentukan oleh peneliti (Mina et al., 2011). Berdasarkan penelitian oleh Cheng \& Church (2000), residue dari elemen $a_{i j}$ dalam bicluster yang ditunjukkan oleh subset $I$ dan $J$ adalah sebagai berikut:

$$
\text { residue }=a_{i j}-a_{i j}-a_{I j}+a_{I J}
$$

di mana $a_{i j}$ adalah rata-rata dari baris ke-i dalam bicluster, $a_{I j}$ adalah adalah rata-rata dari kolom ke-j dalam bicluster, dan $a_{I J}$ adalah rata-rata dari seluruh elemen dalam bicluster. Sementara itu, mean squared residue adalah varians dari himpunan seluruh elemen dalam bicluster ditambah varians baris rata-rata dan varians kolom rata-rata. Dalam hal ini bicluster yang memiliki mean squared residue rendah dengan dimensi yang besar adalah bicluster yang baik. Berikut adalah penghitungan dari mean squared residue.

$$
H(I, J)=\frac{1}{|I||J|} \sum_{i \epsilon I, j \in J}\left(a_{i j}-a_{i J}-a_{I j}+a_{I J}\right)^{2}
$$

di mana:

$$
\begin{aligned}
& a_{i J}=\frac{1}{|J|} \sum_{j \epsilon J} a_{i j}, \quad a_{I j}=\frac{1}{|I|} \sum_{i \epsilon I} a_{i j} \\
& a_{I J}=\frac{1}{|I||J|} \sum_{i \epsilon I, j \epsilon J} a_{i j}=\frac{1}{|I|} \sum_{i \epsilon I} a_{i J}=\frac{1}{|J|} \sum_{j \epsilon J} a_{I j}
\end{aligned}
$$

Kemudian, untuk membandingkan kualitas bicluster hasil dari beberapa $\delta$ yang berbeda, digunakan rasio rata-rata bicluster, yaitu rasio antara residu dan volume sebagai berikut (Chakraborty \& Maka, 2005).

$\frac{1}{b} \sum_{i=1}^{b} \frac{\text { Residue }_{i}}{\text { Volume }_{i}}$

Volume $_{i}=c_{i} \times d_{i} \frac{1}{b} \sum_{i=1}^{b} \frac{\text { Residue }_{i}}{\text { Volume }_{i}}$

di mana:

$$
\text { Residue }_{i}=\text { residu bicluster ke-i }
$$


Volume $_{i}=$ volume bicluster ke-i (dimensi bicluster)

$c_{i}=$ jumlah kolom bicluster ke-i (variabel)

$d_{i}=$ jumlah baris bicluster ke-i (amatan)

$b=$ jumlah bicluster

Melalui rasio tersebut, $\delta$-biclustering yang akan dipilih adalah yang memiliki nilai rasio terkecil. Selain itu, kualitas dari bicluster yang dihasilkan juga dinilai koherensinya melalui nilai varians dari model aditif berikut (Pontes et al., 2015).

$$
b_{i j}=\pi+\beta_{i}+\beta_{j}
$$

di mana $\pi$ adalah nilai dari elemen matriks, sedangkan $\beta_{i}(1 \leq i \leq|I|)$ dan $\beta_{j}(1 \leq j \leq|J|)$ menunjukkan nilai konstan pada model aditif untuk setiap baris $i$ dan kolom $j$. Jika nilai additive variance nol, maka bicluster tersebut secara ideal koheren. Umumnya, nilai di atas 1,5 cukup untuk menentukan bahwa bicluster tersebut tidak koheren.

Metode biclustering CC telah digunakan dalam sejumlah penelitian. Dalam penelitian Yuniarto \& Kurniawan (2017), metode tersebut digunakan untuk memetakan struktur kemiskinan dimensional di Provinsi Jawa Timur. Selain itu, Kaban et al. (2019) juga menggunakan metode tersebut untuk memetakan kabupaten/kota di Indonesia berdasarkan variabel-variabel penyusun social vulnerability index oleh Siagian et al. (2014).

\section{HASIL DAN PEMBAHASAN}

Pengolahan data dilakukan dengan menggunakan $\mathrm{R}$ versi 3.6.1. Proses biclustering diawali dengan menentukan parameter $\delta$. Parameter tersebut ditentukan berdasarkan nilai awal residu dari set data yang akan digunakan. Nilai residu yang diperoleh dalam penelitian ini adalah 0,005153 . Selanjutnya, parameter $\delta$ ditentukan pada interval 0,004638 hingga 0,002061 (90\% hingga $40 \%$ dari nilai residu). Kemudian, dari beberapa parameter tersebut akan dipilih parameter dengan hasil biclustering terbaik.

Pemilihan tersebut dilakukan berdasarkan rata-rata rasio residu terhadap volume (Chakraborty \& Maka, 2005). Hasil biclustering dengan rata-rata rasio terkecil merupakan hasil biclustering terbaik. Hal ini berlandaskan tujuan biclustering untuk menghasilkan bicluster dengan residu minimal dan volume maksimal. Selain itu, jumlah bicluster juga perlu dipertimbangkan. Menurut Symeonidis et al., 2008, jumlah bicluster yang banyak tidak efisien meskipun lebih efektif dalam mengidentifikasi objek data.

Tabel 1. Jumlah bicluster beserta rata-rata rasionya untuk setiap parameter.

\begin{tabular}{ccc}
\hline $\begin{array}{c}\text { Nilai } \\
\text { Parameter } \delta\end{array}$ & $\begin{array}{c}\text { Jumlah } \\
\text { Bicluster }\end{array}$ & $\begin{array}{c}\text { Rata-Rata } \\
\text { Rasio Bicluster }\end{array}$ \\
\hline $40 \% \mathrm{H}$ & 9 & 0,000191 \\
$50 \% \mathrm{H}$ & 7 & 0,000533 \\
$60 \% \mathrm{H}$ & 5 & 0,000187 \\
$70 \% \mathrm{H}$ & 5 & 0,000199 \\
$80 \% \mathrm{H}$ & 5 & 0,000152 \\
$90 \% \mathrm{H}$ & 5 & 0,000324 \\
\hline
\end{tabular}

Sumber : Survei Sosial Ekonomi Nasional 2018 diolah.

Hasil penghitungan pada Tabel 1 menunjukkan bahwa biclustering dengan parameter $\delta=$ $0,004123(80 \%$ residu) menghasilkan rata-rata rasio terkecil, yaitu 0,000152. Oleh karena itu, $\delta=0,004123$ dipilih sebagai parameter terbaik dengan pertimbangan rata-rata rasio terkecil dan jumlah bicluster yang dihasilkan lebih sedikit, yaitu sebanyak lima bicluster. Selain itu, kualitas dari bicluster yang dihasilkan juga dilihat dari koherensinya melalui nilai additive variance berikut.

Tabel 2. Nilai additive variance untuk setiap bicluster.

\begin{tabular}{cc} 
Bicluster & Additive Variance \\
\hline 1 & 0,1621 \\
\hline
\end{tabular}




\begin{tabular}{ll}
\hline 2 & 0,2235 \\
3 & 0,2524 \\
4 & 0,3075 \\
5 & 0,2694 \\
\hline
\end{tabular}

Sumber : Survei Sosial Ekonomi Nasional 2018 diolah.

Tabel 2 menunjukkan nilai additive variance dari setiap bicluster yang dihasilkan dengan menggunakan $\delta=0,004123$. Dari hasil tersebut terlihat bahwa setiap bicluster yang dihasilkan memiliki nilai additive variance kurang dari 1,5. Hal ini membuktikan bahwa bicluster-bicluster tersebut koheren. Selanjutnya, berikut adalah ringkasan hasil pengelompokan kabupaten/kota di Indonesia menurut bicluster yang dihasilkan.

Tabel 3. Pengelompokan kabupaten/kota berdasarkan biclustering.

\begin{tabular}{ccc}
\hline Bicluster & $\begin{array}{c}\text { Jumlah } \\
\text { Kabupaten/Kota }\end{array}$ & $\begin{array}{c}\text { Jumlah Variabel } \\
\text { Penciri }\end{array}$ \\
\hline 1 & 434 & 9 \\
2 & 44 & 8 \\
3 & 22 & 8 \\
4 & 9 & 6 \\
5 & 5 & 6 \\
\hline Sumber : Survei Sosial Ekonomi Nasional 2018 diolah.
\end{tabular}

Tabel 3 menunjukkan bahwa sebagian besar wilayah Indonesia merupakan anggota bicluster 1 dengan jumlah kabupaten/kota sebanyak 434. Selanjutnya, terdapat 44 kabupaten/kota pada bicluster 2, 22 kabupaten/kota pada bicluster 3, 9 kabupaten/kota pada bicluster 4, dan 5 kabupaten/kota pada bicluster 5 . Berikut adalah gambaran karakteristik dari setiap bic/uster secara keseluruhan.

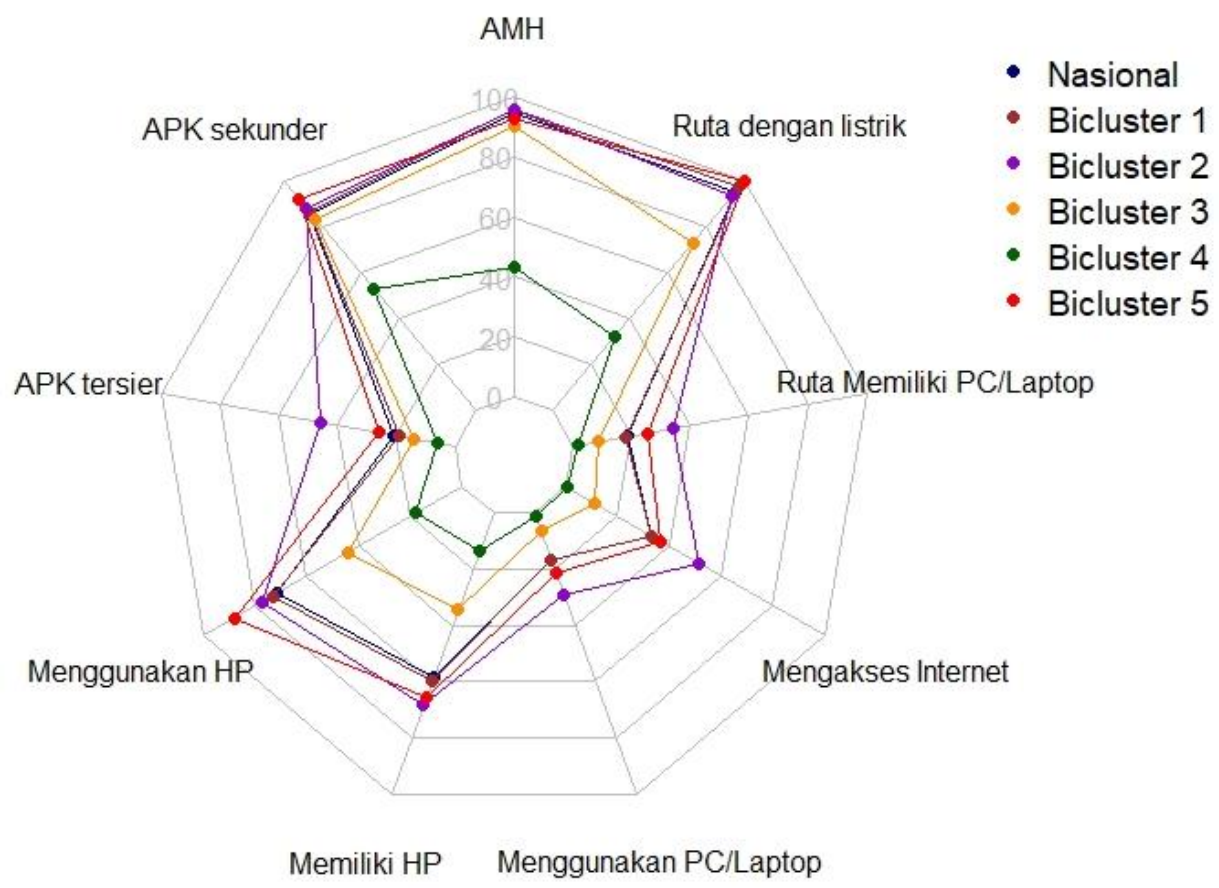

Gambar 2. Radar plot rata-rata variabel di setiap bicluster.

Gambar 2 menunjukkan radar plot yang membandingkan rata-rata variabel di setiap bicluster yang terbentuk. Dari gambar tersebut terlihat bahwa antara bicluster 1, 2, dan 5 tidak menunjukkan perbedaan yang begitu berarti. Berbeda halnya dengan bicluster 3 dan 4 yang menunjukkan hasil sebaliknya. Hal ini mengindikasikan bahwa kabupaten/kota yang tidak siap 
atau sangat tidak siap sebagian besar terkonsentrasi pada bicluster-bicluster tersebut, terutama bicluster 4.

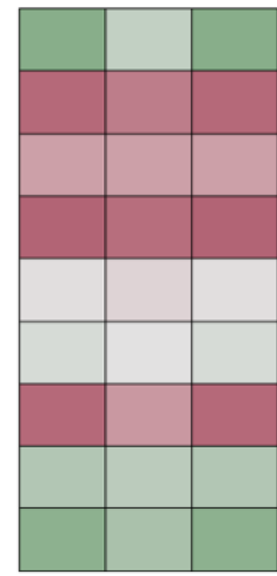

1

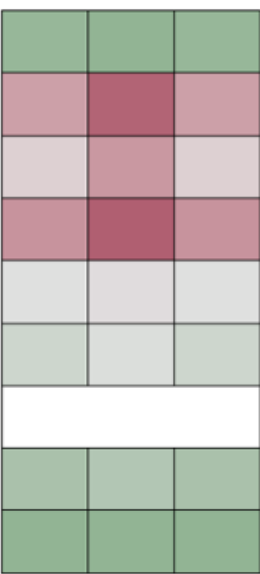

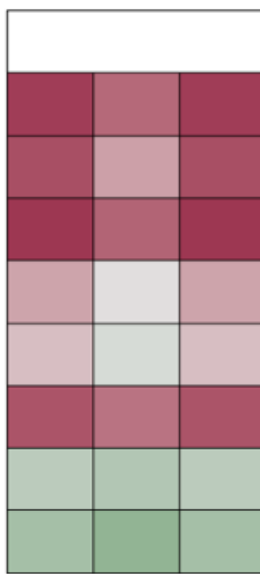

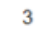

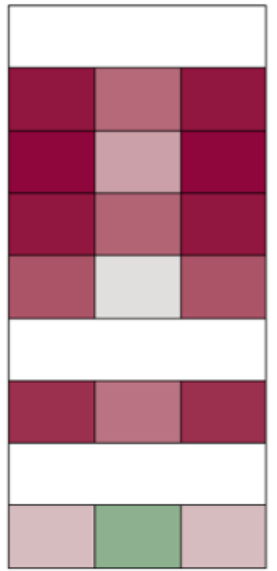

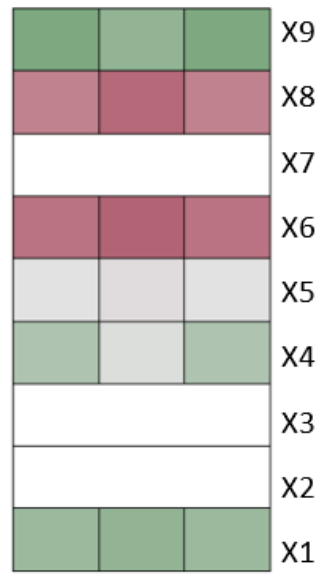

$\mathrm{X} 1$

Gambar 3. Grafik keanggotaan bicluster berdasarkan variabel pencirinya.

Selanjutnya, Gambar 3 menunjukkan grafik keanggotaan variabel-variabel penciri untuk setiap bicluster. Dari gambar tersebut terlihat bahwa pada umumnya setiap kabupaten/kota di Indonesia masih perlu berbenah terkait pendidikan tinggi dan akses internet beserta perangkat utilitasnya. Hal ini ditunjukkan oleh rendahnya APK tersier, penggunaan PC/laptop dan akses internet oleh individu, serta kepemilikan aset PC/laptop di rumah tangga. Selain itu, terlihat pula bahwa bicluster 4 memiliki nilai terendah di setiap variabel dibandingkan bicluster lainnya. Kemudian, posisi terendah berikutnya diduduki oleh bicluster 3. Sementara itu, dari gambar tersebut terlihat bahwa pola warna pada bicluster 1, 2, dan 5 tidak menunjukkan perbedaan yang begitu berarti.

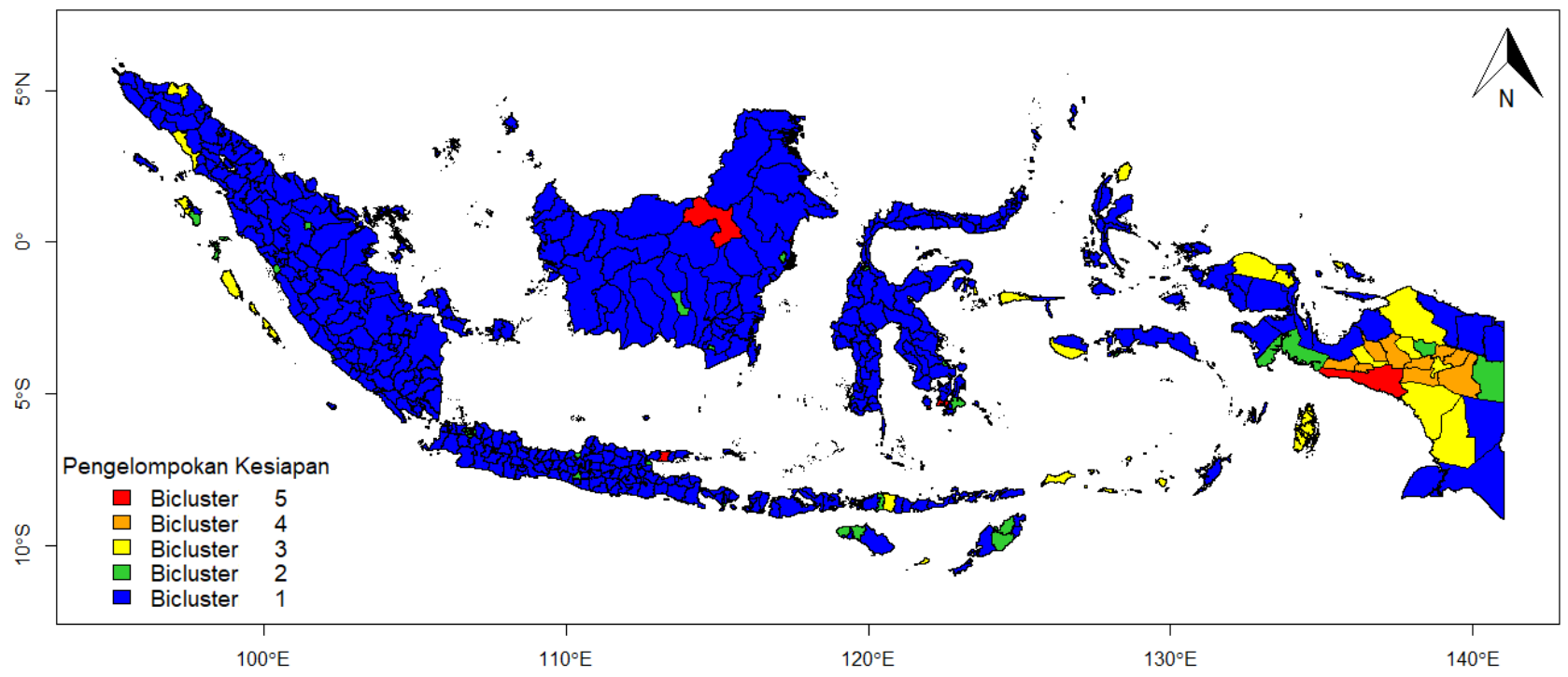

Gambar 4. Peta pengelompokan kabupaten/kota dengan biclustering.

Berikutnya, Gambar 4 menunjukkan peta persebaran kabupaten/kota di Indonesia berdasarkan pengelompokan biclustering. Dari gambar tersebut tampak bahwa pada umumnya kabupaten/kota di seluruh Indonesia berada pada bicluster 1 . Untuk bicluster 2, sebanyak 7 observasi berada di Pulau Sumatera, 16 observasi di Pulau Jawa, dan sisanya tersebar secara acak. Sementara itu, persebaran bicluster 3 dan bicluster 4 tekonsentrasi pada wilayah timur 
Indonesia dan 5 observasi pada bicluster 5 tersebar secara acak. Hal ini membuktikan bahwa wilayah timur Indonesia, khusunya Papua masih tertinggal dibandingkan wilayah-wilayah lainnya di Indonesia. Hasil tersebut sejalan dengan penelitian oleh Ariyanti (2016) dan Al-Mursyid (2020) yang menyatakan bahwa infrastruktur TIK dan penggunaan internet untuk wilayah tersebut masih minim.

\section{KESIMPULAN}

Metode pengelompokan dengan biclustering mampu mengelompokkan kabupaten/kota ke dalam 5 bicluster berdasarkan karakteristik dari setiap variabel indikator kesiapan dalam menghadapi revolusi industri 4.0. Masing-masing bicluster memiliki variabel penciri yang dapat memudahkan pemerintah untuk menetapkan kebijakan sesuai dengan kondisi dari setiap daerah di tiap variabelnya. Penelitian ini menunjukkan bahwa bicluster 3 dan 4 adalah dua kelompok dengan nilai terendah dibandingkan bicluster lainnya untuk setiap variabel. Kedua bicluster tersebut terkonsentrasi di wilayah timur, khususnya Papua. Dari hasil tersebut pemerintah perlu menjadikan wilayah timur, khususnya Papua sebagai prioritas utama dalam mempersiapkan masyarakatnya untuk menghadapi revolusi industri 4.0 melalui pendidikan dan pembangunan infrastruktur TIK. Selain itu, beberapa wilayah terdepan di bagian barat juga memerlukan pembenahan terkait aspek-aspek tersebut. Di sisi lain, diduga kondisi geografis yang sulit dijangkau dan topografi pegunungan di wilayah Papua merupakan penyebab terhambatnya pembangunan infrastruktur pendidikan dan TIK.

\section{UCAPAN TERIMA KASIH}

Terima kasih saya ucapkan kepada dosen pembimbing yang telah bersedia untuk memberikan ilmu dan arahannya dalam melakukan penelitian ini.

\section{DAFTAR PUSTAKA}

Al-Mursyid, A. R. (2020). Pengaruh Pembangunan Teknologi Informasi dan Komunikasi Terhadap Pembangunan Kawasan Timur Indonesia. Jurnal Ekonomi Pembangunan STIE Muhammadiyah Palopo, 5(2).

Ariyanti, S. (2016). Studi pengukuran digital divide di Indonesia. Buletin Pos dan Telekomunikasi, 11(4), 281-292.

Baller, S., Dutta, S., \& Lanvin, B. (2016). Global information technology report 2016. Geneva: Ouranos.

Breene, Keith. (2016). "What is 'Networked Readiness Index' and Why Does It Matter?". Diakses pada tanggal 11 September 2019 melalui https://www.weforum.org/agenda/2016/07/what-is-networkedreadiness-and-why-does-it-matter/.

Burma, Z. A. (2016). 4th Industrial Revolution and Innovating in the Digital Economy: World and Turkey Values for 2016 by Global Indicators. International Journal of Research in Engineering, IT and Social Sciences, 6(12), 20-33.

Chakraborty, A., \& Maka, H. (2005, November). Biclustering of gene expression data using genetic algorithm. In 2005 IEEE Symposium on Computational Intelligence in Bioinformatics and Computational Biology (pp. 1-8). IEEE.

Chang, J. H., \& Huynh, P. (2016). ASEAN in transformation the future of jobs at risk of automation (No. 994906463402676). International Labour Organization.

Cheng, Y., \& Church, G. M. (2000, August). Biclustering of expression data. In Ismb (Vol. 8, No. 2000, pp. 93-103).

Kaban, P. A., Kurniawan, R., Caraka, R. E., Pardamean, B., \& Yuniarto, B. (2019). Biclustering Method to Capture the Spatial Pattern and to Identify the Causes of Social Vulnerability in Indonesia: A New Recommendation for Disaster Mitigation Policy. Procedia Computer Science, 157, 31-37.

Kaiser, S. (2011). Biclustering: methods, software and application (Doctoral dissertation, Imu).

Kementerian Perindustrian RI. (2018). Making Indonesia 4.0. Diakses dari https://www.kemenperin.go.id/download/18384 pada 11 November 2019. 
Mina, E., Feelders, A. J., Kemmeren, P., \& Siebes, A. P. J. M. (2011). Applying biclustering to understand the molecular basis of phenotypic diversity. Phd. Utrecht University Faculty of Science Department of Information and Computing Sciences.

Pontes, B., Girldez, R., \& Aguilar-Ruiz, J. S. (2015). Quality measures for gene expression biclusters. PloS one, 10(3).

Satya, V. E. (2018). Strategi Indonesia Menghadapi Industri 4.0. Info Singkat, 10(9), 19-24.

Schwab, Klaus. (2016). "The Fourth Industrial Revolution: What It Means, How To Respond". Diakses pada tanggal 11 November 2019 melalui https://www.weforum.org/agenda/2016/01/the-fourth-industrialrevolution-what-it-means-and-how-to-respond.

Sony, M., \& Naik, S. (2019). Key ingredients for evaluating Industry 4.0 readiness for organizations: a literature review. Benchmarking: An International Journal.

World Economic Forum \& Asian Development Bank (ADB). (2017). ASEAN 4.0: what does the Fourth Industrial Revolution mean for regional economic integration?. World Economic Forum, Geneva.

Yuniarto, B., \& Kurniawan, R. (2017). Understanding Structure of Poverty Dimensions in East Java: Bicluster Approach. Signifikan: Jurnal Ilmu Ekonomi, 6(2), 289-300. 